\title{
My contact and cooperation with Govindjee over the last five decades: Chlorophyll fluorescence and Rebeiz Foundation
}

\author{
H.K. LICHTENTHALER \\ Botanical Institute II, Molecular Biology and Biochemistry of Plants, Karlsruhe Institute of Technology (KIT), \\ D-76133 Karlsruhe, Germany
}

\begin{abstract}
Govindjee and Hartmut Lichtenthaler have a very similar curriculum vitae. Both chose photosynthesis as research field and actively applied chlorophyll fluorescence. Their research was overlapping and complementary. On the occasion of Govindjee's $88^{\text {th }}$ anniversary in 2020, Hartmut Lichtenthaler gives a short retrospective on interactions and joint activities with Govindjee over the past five decades.
\end{abstract}

Additional key words: Andy Benson; chlorophyll fluorescence decrease ratio; chlorophyll fluorescence imaging; Constantin Rebeiz; Hans Kautsky; Robert Emerson.

\section{Introduction}

Govindjee, born in 1932 in Allahabad, India, received his Ph.D. at the University of Illinois, Urbana, in 1960 with Eugene Rabinowitch, and I, Hartmut Lichtenthaler, born two years later in 1934, received my Ph.D. at the University of Heidelberg, Germany, in 1961 with August Seybold known for his detailed analysis of the chlorophylls and individual carotenoids in green leaves (Seybold and Egle 1937). Although coming from quite different parts of the world, we both chose photosynthesis as our main research field and dealt with related topics, especially with the light-induced chlorophyll $a$ fluorescence as means to analyze and understand the photosynthetic processes of green plants and to detect stress conditions.

\section{The annual ASPP meeting in 1963 in Amherst}

Govindjee and I met first in 1963 at the annual ASPP (American Society of Plant Physiology, now Biology) meeting held in Amherst, Massachusetts, from 26 to 29 August. We both were young scientists, presenting our newest research findings. He had worked with Eugene Rabinowitch (during 1958-1960) at the University of Illinois, Urbana, and had just been appointed assistant professor there. I worked from 1962-1964 as research fellow in Melvin Calvin's laboratory in Berkeley, California. In the 'Photosynthesis Session' of that meeting,
Govindjee talked about chlorophyll (Chl) fluorescence induction kinetics, the existence of two light reactions and their meaning for photosynthetic quantum conversion. His results were already in press and appeared in the same year (Govindjee 1963). He spoke very fast and, like most people in the audience, I did not realize the real meaning of these Chl fluorescence data. In fact, this field of photosynthesis research was practically new to almost all of the participants. In the same session, shortly after Govindjee, I reported on the chlorophyll, carotenoid, and prenylquinone (plastoquinone-9, phylloquinone vitamin $\mathrm{K}_{1}$ ) composition of chloroplasts and their smallest units, then termed 'quantasomes'. My findings were also in press (Lichtenthaler and Park 1963, Lichtenthaler and Calvin 1964).

This Photosynthesis Session in Amherst involved only about 25 people, among them were well-known photosynthesis researchers, such as the Nobel Laureate of 1961, Melvin Calvin (1911-1997), Hans Gaffron (19021979), and Eugene Rabinowitch (1901-1973). Arthur Galston (1920-2008), then President of ASPP, participated as well. Part of the open informal discussion in this session dealt with the possible existence of two photosynthetic light reactions, a concept that was in progress and not yet fully accepted at that time. That Chl fluorescence would become a major technique to study photosynthetic processes and the two photosystems, could not be anticipated at that time.

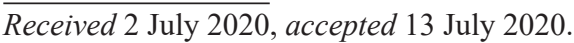

E-mail: hartmut.lichtenthaler@kit.edu

Abbreviations: $\mathrm{Chl}$ - chlorophyll; $\mathrm{F}_{0}$ - ground chlorophyll fluorescence; $\mathrm{F}_{\mathrm{d}}-\mathrm{Chl}$ fluorescence decrease from maximum to the steady state; $\mathrm{F}_{\mathrm{m}}-$ maximum $\mathrm{Chl}$ fluorescence; $\mathrm{F}_{\mathrm{s}}$ - steady state $\mathrm{Chl}$ fluorescence; $\mathrm{F}_{\mathrm{v}}-$ variable Chl fluorescence; $P_{\mathrm{N}}-$ photosynthetic net $\mathrm{CO}_{2}$ assimilation rate; $\mathrm{R}_{\mathrm{Fd}}-\mathrm{Chl}$ fluorescence decrease ratio $\mathrm{F}_{\mathrm{d}} / \mathrm{F}_{\mathrm{s}}$.

Acknowledgements: I wish to thank Govindjee, Urbana-Champaign, and Tom Sharkey, East Lansing, Claus Buschmann and Manfred Focke, both at Karlsruhe, for valid information during the preparation of this text. 


\section{The early chlorophyll fluorescence measurements}

In 1931, the chemist and former painter Hans Kautsky (1891-1966), while working at the University of Heidelberg, detected and described in German the red chlorophyll (Chl) fluorescence induction kinetics in green plant tissue and correctly characterized the fast fluorescence rise, followed by a slow decrease to a very low steadystate fluorescence in all the details and variations due to e.g., light intensity and temperature (Kautsky and Hirsch 1931). And above all, this was done with bare eyes, in a darkened room. These authors correctly attributed the fluorescence decrease to the onset of photosynthetic $\mathrm{CO}_{2}$ assimilation ('Kohlensäureassimilation') and showed that it was blocked by hydrogen cyanide. In this paper, they also stated that "the larger the proportion of absorbed radiation converted into chemical energy, the lower the Chl fluorescence intensity in the steady state". In the following years, Kautsky and co-workers published several other papers on the $\mathrm{Chl}$ fluorescence induction kinetics (see the review by Lichtenthaler 1992). Yet only in 1943, in the paper published together with his Ph.D. student Ulrich Franck, then working at the University of Leipzig, Kautsky presented evidence that the photosynthetic light reactions not only cause an increase but also a decrease of Chl fluorescence (Kautsky and Franck 1943). In this paper (his $\mathrm{XI}^{\text {th }}$ communication), again written in German, Kautsky stated for the first time that during the process of photosynthesis "two light reactions succeed one another almost immediately" (in German: "dass zwei Lichtreaktionen fast unmittelber aufeinanderfolgen"). After a 17-year break, in his Chl fluorescence publications, due to World War II, Kautsky in 1960 summarized his Chl fluorescence results, obtained since 1955 at the University of Marburg, in a review. In this paper (his $\mathrm{XIII}^{\text {th }}$ and last communication on Chl fluorescence), he emphasized again that two consecutive light reactions worked in photosynthesis (Kautsky et al. 1960). I attach here a picture of Hans Kautsky at the age of about 60 years (Fig. 1). This picture is a gift of my colleague, the chemist Prof. Gerhard Fritz (1919-2002), Karlsruhe, who was a Ph.D. student and scientific assistant of Hans Kautsky at the University of Marburg, Germany, in the years before Kautsky's retirement in 1959.

Kautsky's early research on $\mathrm{Chl}$ fluorescence and $\mathrm{CO}_{2}$ assimilation of 1931 to 1937 had inspired other scientists such as Stacy French (1907-1995) and James Franck (1882-1964) (Franck et al. 1941), and E. C. Wassink (Wassink and Katz 1939). These scientists measured and described many further details of the Chl fluorescence induction kinetics in leaves and algae and their dependence on various factors, but did not state or mention photochemical light reactions. In the late 1950s, Kautsky's original findings on $\mathrm{Chl}$ fluorescence, published between 1931 and 1943, seemed to have been more or less forgotten. But this field of $\mathrm{Chl}$ fluorescence research was independently and successfully restarted by Govindjee as shown below, and both with and after him also by Louis N. M. Duysens (Duysens and Sweers 1963) and various other researchers, including Warren L. Butler (Butler 1962).

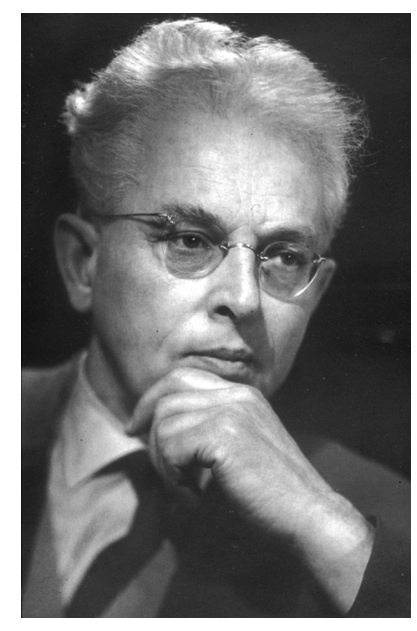

Fig. 1. Photo of Hans Kautsky at the age of about 60 years, then working at the University of Marburg, Germany. (Photo from H.K. Lichtenthaler)
In 1957, Robert Emerson (1903-1959) had made his essential observation on the enhancement of photosynthesis in far-red light by additional light of shorter wavelengths, which became known as 'Emerson enhancement effect' (Emerson et al. 1957). Govindjee, who had been a graduate student of Robert Emerson at the University of Illinois, started there his Chl fluorescence investigations of photosynthesis, which he continued even after Emerson's early death in 1959 in the laboratory of Eugene Rabinowitch. He studied the two-light effect via Chl fluorescence by combining far-red light with shorter wave light on the excitation of Chl fluorescence in Chlorella and clearly discovered the existence of two separate photosystems (Govindjee et al. 1960). This was summarized in his further paper 'Emerson enhancement effect and two light reactions in photosynthesis' (Govindjee 1963). His essential findings were clearly recognized by Duysens and Sweers (1963) who wrote in their paper that "the first experimental suggestion of a different effect on fluorescence of two light beams of different colors was obtained by Govindjee et al. (1960)". In this paper, Duysens also acknowledged Kautsky's last findings of 1960 on two consecutive photosynthetic light reactions by mentioning "a recent paper of Kautsky et al. 1960 contains a scheme which is formally similar to ours".

When Govindjee had started his Chl fluorescence investigations in Emerson's and later in Rabinowitch's laboratory, he did not know about the investigations of Kautsky. Being asked on this point he answered me "Kautsky's observations on chlorophyll fluorescence were mentioned only casually as simply old fashioned observations, because the Rabinowitch Lab was already into making nanosecond lifetime fluorescence measurements and absolute quantum yield of fluorescence. Then, we had visitors like Stacy French (1907-1995) who had done much advanced work together with James Franck".

Via his sensitive absorption spectroscopy and action spectra investigations in 1961, Louis Duysens (1921-2015) had excellently documented the light-induced reduction and oxidation of cytochrome (Duysens et al. 1961; also see Blankenship 2014, pages 35 and 36) and thus proved that there are two photosynthetic light reactions. These essential 
results were further supplemented by his following paper including Chl fluorescence measurements (Duysens and Sweers 1963). Many years later in 1986, I participated on a photosynthesis workshop in the Netherlands, where Louis Duysens (Govindjee and Pulles 2016) gave an afterdinner talk. He was introduced as 'the detector of the two light reactions in photosynthesis'. Duysens immediately answered on this introduction with the admission that, when he started his investigations in the 1950s, he had read the early work of Kautsky and had been influenced in his research by Kautsky's statement of two light reactions in photosynthesis. He admitted that "somehow I had pushed this aside in my mind when I published my results in 1961".

Govindjee extended and continued his promising Chl fluorescence research started in the late 1950s in many different ways and approaches including low temperature fluorescence spectroscopy (see e.g., Eaton-Rye 2019). In fact, Chl fluorescence kept him busy his full lifetime as active researcher and made him to one of the leading experts on Chl fluorescence. His success and high international recognition were essentially promoted by his open and communicative way to discuss with other researchers and by his worldwide scientific cooperation.

\section{The First International Photosynthesis Congress 1968 in Freudenstadt}

In 1968, Helmut Metzner (1925-1999), of Tübingen, initiated and organized the first International Photosynthesis Congress, from June 4-8, in Freudenstadt in the Black Forest, Germany. This was the first international meeting after World War II, where scientists from the East and the West came together and for the first time could discuss and exchange their recent photosynthetic research results. Leading photosynthesis researchers participated, such as Alexander A. Krasnowsky (1913-1993), Moscow, Melvin Calvin (1911-1997), Berkeley, and Trevor Goodwin (1916-2008), Wales, as well as many younger scientists and also Zdeněk Šesták (1932-2008), who in 1967 in Prague had founded the journal Photosynthetica (Govindjee et al. 2002, Lichtenthaler 2018). In fact, this meeting was the starting point for international cooperation that continued for the next decades.

Govindjee had been invited to present his newest Chl fluorescence results, both on the second (Munday and Govindjee 1969) and the minute time scale (Papageorgiou and Govindjee 1969) and their relation to the functioning of the two photosystems. In turn, I reported the $\mathrm{Chl}$ and prenylquinone composition of the two photosystems presenting first evidence that phylloquinone $\mathrm{K}_{1}$ was bound to photosystem I particles (Lichtenthaler 1969), later described in full detail (see Interschick-Niebler and Lichtenthaler 1981).

\section{Further contacts with Govindjee in the 1970s and 1980s}

My interest in Chl fluorescence started in summer 1969. After a lecture I had given at the University of Aachen, Germany, I had the chance to talk to the physical chemist
Prof. Ulrich Franck, Kautsky's former Ph.D. student of 1943, and his co-worker Ulrich Schreiber on their detailed measurements of $\mathrm{Chl}$ fluorescence as indicator of the photochemical primary processes of photosynthesis (Franck et al. 1969). Shortly later in 1970, when I was appointed full professor at the University of Karlsruhe, Germany, I broadened my photosynthesis research and started to apply Chl fluorescence kinetics as a measure to gain quick, nondestructive and reliable information on the photosynthetic $\mathrm{CO}_{2}$ assimilation rates of leaves. Applying it first in our herbicide research we could show that the slow decrease of the Chl fluorescence from $\mathrm{F}_{\mathrm{m}}$ to the steady state $\mathrm{F}_{\mathrm{s}}$ was blocked by the new herbicide bentazone which acted in the same way as diuron (Pfister et al. 1974), the target of both herbicides being the $\mathrm{Q}_{\mathrm{B}}$-protein as was shown later by several groups. In addition and based on Kautsky's observation (Kautsky and Hirsch 1931), I concentrated on the relative amounts of the Chl fluorescence decrease $F_{d}$, which was higher in sun than that in shade leaves and reflected the higher photosynthetic activity of sun leaves as compared to shade leaves. In the mid-1970s, Govindjee and I met again, this time on an international photochemistry conference in Germany, where we talked about our complementary Chl fluorescence findings and our ideas for future research.

Concerning the application of $\mathrm{Chl}$ fluorescence, Govindjee and most other researchers continued their research by mainly focusing on 'Photosystem II' and dealing with details of the light-induced fluorescence rise kinetics (O-J-I-P rise) and their variation and modification by various external and internal factors and chemical compounds such as shown in a more recent paper (Stirbet and Govindjee 2011). In this context, see also the review of Lichtenthaler et al. (1998) (particularly Fig. 3 on page 275). In contrast, I concentrated on the slow decrease of Chl fluorescence from the maximum $\mathrm{F}_{\mathrm{m}}$ to the steadystate fluorescence $F_{s}$. Here $I$ introduced the ratio of the fluorescence decrease $F_{d}$ (from $F_{m}$ to $F_{s}$ ) to the steadystate fluorescence $\mathrm{F}_{\mathrm{s}}$, i.e., the $\mathrm{R}_{\mathrm{Fd}}$ ratio $\left(\mathrm{F}_{\mathrm{d}} / \mathrm{F}_{\mathrm{s}}\right)$ (see Fig. 2, upper part), the values of which directly correlated with the photosynthetic $\mathrm{CO}_{2}$ assimilation rates of leaves (Fig. 2, lower part). The photosynthetic rates $\left(P_{\mathrm{N}}\right)$ of shade leaves were in the range of 0.1 to 3.8 and those of sun leaves in the range of 4.8 to $12 \mu \mathrm{mol}\left(\mathrm{CO}_{2}\right) \mathrm{m}^{-2} \mathrm{~s}^{-1}$. In fact, the $\mathrm{R}_{\mathrm{Fd}}$ ratio proved to be an excellent indicator of stress conditions in plants (e.g., Lichtenthaler and Rinderle 1988, Lichtenthaler and Babani 2004, Lichtenthaler et al. 2005a).

Our exchange was intensified in August 1983 at the $6^{\text {th }}$ International Photosynthesis Congress in Brussels organized by Chris Sybesma (see Vredenberg and Govindjee 2020) and shortly afterwards on the conference 'Herbicides Active in Chloroplasts' in Wageningen, Netherlands. In fact, the application of $\mathrm{Chl} a$ fluorescence in the detection of new herbicide compounds binding to the $\mathrm{Q}_{\mathrm{B}}$-protein of 'Photosystem II' was a major topic of that conference. I remember well the informal and good discussion we had in the evening, together with other colleagues, in the bar at the top of the university tower there. Govindjee and I had always respected one another and our science approaches, 

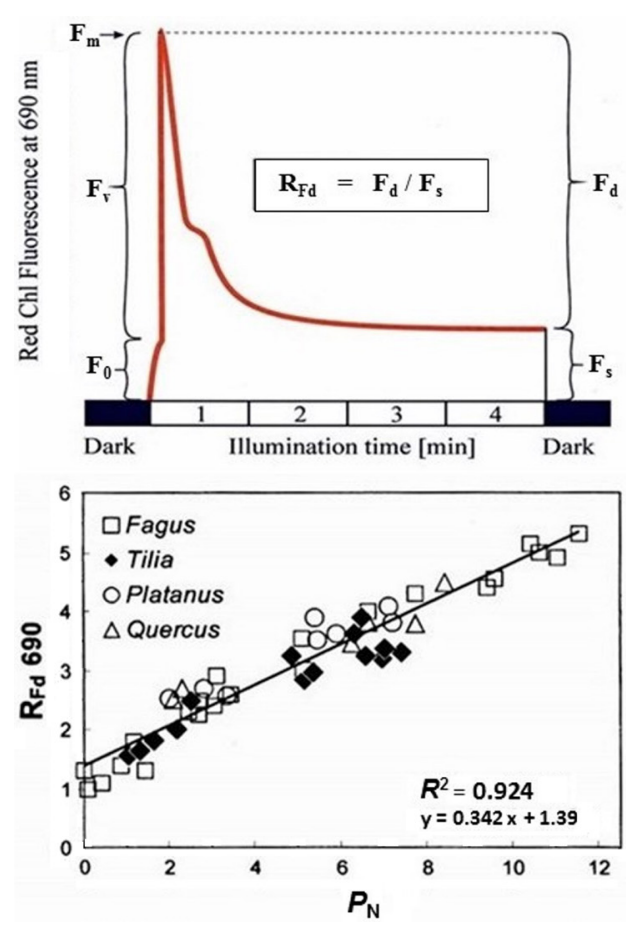

Fig. 2. Upper part: Light-induced chlorophyll (Chl) fluorescence induction kinetics (Kautsky effect) in pre-darkened green leaves measured at light saturation. Lower part: Linear correlation of the chlorophyll fluorescence decrease ratio $\mathrm{R}_{\mathrm{Fd}}$ with the photosynthetic net $\mathrm{CO}_{2}$ fixation rate $\left(P_{\mathrm{N}}\right)$ at light saturation shown here for sun and shade leaves of several trees. $\mathrm{F}_{0}-$ ground chlorophyll fluorescence; $F_{d}-$ Chl fluorescence decrease from maximum to the steady state; $F_{m}-$ maximum $\mathrm{Chl}$ fluorescence; $\mathrm{F}_{\mathrm{s}}$ - steady state $\mathrm{Chl}$ fluorescence; $\mathrm{F}_{\mathrm{v}}$ - variable Chl fluorescence; $\mathrm{R}_{\mathrm{Fd}}$ - Chl fluorescence decrease ratio $\mathrm{F}_{\mathrm{d}} / \mathrm{F}_{\mathrm{s}}$. (Based on Lichtenthaler and Rinderle 1988, Lichtenthaler et al. 2004, 2005b)

and we became close friends. Since then we had regular contact, and we met on various other congresses and meetings of our worldwide photosynthetic community. Chl fluorescence and its application in photosynthesis research remained Govindjee's and my major research topic. In fact, our individual $\mathrm{Chl}$ fluorescence publications were complementary and would influence or even stimulate the other one of us to new research approaches or activities.

Like me, Govindjee has had much interest in historical matters of photosynthesis research. When I realized that most of the research papers of Hans Kautsky were not known to the people working on Chl fluorescence, since all of these were written in German language, I wrote a detailed review on all Chl fluorescence papers published by Hans Kautsky and coworkers between 1931 and 1960, just concentrating on Kautsky's essential findings. The title was 'The Kautsky effect: 60 years of chlorophyll fluorescence induction kinetics' (Lichtenthaler 1992). Govindjee was in some way stimulated by this article and some years later published his review ' 63 years since Kautsky: Chlorophyll a fluorescence' (Govindjee 1995) then reporting on the major findings by him and others since the early times of Kautsky.

In 1988, I had organized the 'First International Symposium on Chlorophyll Fluorescence' in Bad Honnef, Germany. The major contributions of this meeting were published in the book 'Applications of Chlorophyll Fluorescence in Photosynthesis Research, Stress Physiology, Hydrobiology and Remote Sensing' (Lichtenthaler 1988). This book as well as the comprehensive review on the application of $\mathrm{Chl}$ fluorescence in photosynthesis research and its successful application in stress detection of plants (Lichtenthaler and Rinderle 1988) considerably stimulated and enhanced the application of Chl fluorescence techniques by other research groups as did several reviews of Govindjee and the book that he had edited together with two colleagues in 1986 (Govindjee et al. 1986). Moreover, in 2004, Govindjee, together with George Papageorgiou, edited the book 'Chlorophyll $a$ fluorescence, a signature of photosynthesis' (Papageorgiou and Govindjee 2004) and, of course, I was invited to contribute a major article (Lichtenthaler and Babani 2004).

\section{Activities after our retirement}

Govindjee retired and became emeritus professor in 1999 , and I became emeritus professor in 2001 . In the following years, we both remained active in research and publishing, again with similar and parallel activities. Govindjee became interested in fluorescence lifetime imaging and applied fluorescence lifetime imaging microscopy (Holub et al. 2000, 2007; Matsubara et al. 2011). In 1983, Govindjee had become associate editor of the journal 'Photosynthesis Research', acted as co-editor-in-chief from 1985 until 1988, yet thereafter he remained editor of the 'Historical Corner', which he had already started in this journal in 1980. After his retirement, he intensified his activity as excellent editor of historical perspectives of Photosynthesis Research. In this function, he wrote many tributes for colleagues who had passed away and had essentially contributed to our present knowledge of photosynthesis and related topics in plant biochemistry. Several of these tributes are mentioned in this report. In addition, he remained editor of the Series 'Advances in Photosynthesis and Respiration', which he had founded in 1994.

In turn, I intensified the imaging of Chl fluorescence and photosynthetic activity of whole leaves (Lichtenthaler and Miehé 1997) and further developed and simplified this technique for routine application (Lichtenthaler et al. 2000, 2005a,b).With each Chl fluorescence image several thousand Chl fluorescence pixels of each leaf were simultaneously measured at $\mathrm{Chl}$ fluorescence maximum $F_{m}$, and then again several minutes (usually $5 \mathrm{~min}$ ) after onset of saturating illumination at steady fluorescence $F_{s}$. The corresponding images of the $R_{F d}$ values (Fig. 3) revealed large gradients in $\mathrm{R}_{\mathrm{Fd}}$ values and correspondingly in the photosynthetic $\mathrm{CO}_{2}$ assimilation rates $P_{\mathrm{N}}$ over different parts of the leaf area, both in sun and shade leaves of the beech. Such large gradients were not known or anticipated before. The $\mathrm{R}_{\mathrm{Fd}}$ images shown in Fig. 3 clearly demonstrate the higher $\mathrm{R}_{\mathrm{Fd}}$ values in sun 

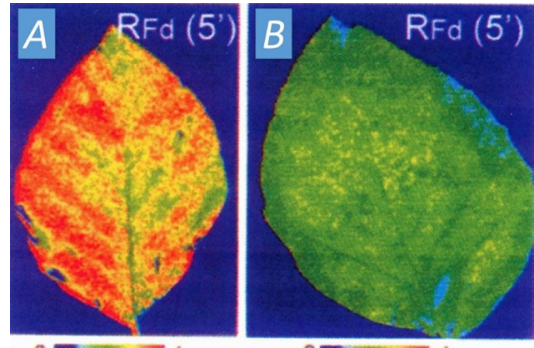

Fig. 3. Images of the chlorophyll (Chl) fluorescence decrease ratio $\mathrm{R}_{\mathrm{Fd}}$, a measure of the net photosynthesis rates $P_{\mathrm{N}}$, of a sun $(A)$ and a shade leaf $(B)$ of beech (Fagus sylvatica $\mathrm{L}$.). The Chl fluorescence decrease ratio images $\mathrm{R}_{\mathrm{Fd}}$ were determined from the Chl fluorescence images taken first at $F_{m}$ and then at $F_{s}$. The $\mathrm{Chl}$ fluorescence images at $\mathrm{F}_{\mathrm{s}}$ were measured 5 min after onset of continuous illumination of the pre-darkened leaves. As a consequence, the $R_{F d}$ values were termed here $R_{F d}\left(5^{\prime}\right)$. The measurements were performed with the Karlsruhe FlashLamp Fluorescence Imaging System (FL-FIS) at the red Chl fluorescence maximum near $690 \mathrm{~nm} . \mathrm{F}_{\mathrm{d}}-\mathrm{Chl}$ fluorescence decrease from maximum to the steady state; $F_{m}$ - maximum Chl fluorescence; $\mathrm{F}_{\mathrm{s}}-$ steady state Chl fluorescence; $\mathrm{R}_{\mathrm{Fd}}-\mathrm{Chl}$ fluorescence decrease ratio $\mathrm{F}_{\mathrm{d}} / \mathrm{F}_{\mathrm{s}}$. (Based on Lichtenthaler et al. 2000, Lichtenthaler and Babani 2004)

as compared to shade leaves, as had been demonstrated before via $\mathrm{Chl}$ fluorescence measurements of individual points of sun and shade leaves (see Fig. 2, lower part). In addition, during a visit of the experimental research station in the Czech Beskydy Mountains I measured together with Czech colleagues images of the fluorescence decrease ratio ( $\mathrm{R}_{\mathrm{Fd}}$ images) of sun and shade leaves of four tree species (Lichtenthaler et al. 2007). By combining different parts from several instruments, being available at the research station, we had spontaneously composed a functioning $\mathrm{Chl}$ fluorescence imaging system to be applied for this research. Moreover, I remained co-editor of 'Plant Physiology and Biochemistry' and continued to be active on the Board of several plant physiology journals as well as of Photosynthetica from 1991 to 2005. Occasionally I could contribute to the tributes written by Govindjee, e.g., to that of René Marcelle, the first editor-in-chief of Photosynthesis Research (Govindjee and Marcelle 2016), whom in 1980 I had assisted, already beforehand and then as Board Member, to successfully start and run the new journal 'Photosynthesis Research'. I also continued to write on historical matters in plant physiology, such as the history of the Federation of European Societies of Plant Physiology (FESPP) (Lichtenthaler 2004a) and of the International Symposia on Plant Lipids, ISPL (Lichtenthaler 2004b). Moreover, for several journals I started to write very personal tributes for colleagues of our photosynthetic community, who had passed away, e.g., Zdeněk Šesták, the founder of the journal Photosynthetica (Lichtenthaler 2018) and Roland Douce, who is wellknown for his research on the chloroplast envelope (Joyard and Lichtenthaler 2019) and also Peter Böger, Konstanz (Lichtenthaler 2016). Here, I followed the excellent examples that Govindjee had written in a very personal way about other colleagues.

\section{Contacts during the Symposium on Chloroplast Bioengineering}

In May 2005, Constantin (Tino) Rebeiz (1936-2019), well-known for his excellent research on chlorophyll biosynthesis (Rebeiz 2013, Govindjee et al. 2020a), organized together with colleagues the 'International Symposium on Chloroplast Engineering' in UrbanaChampaign, Illinois. In this symposium, I was involved as co-organizer being responsible for and leading the session on isoprenoid lipids and the new plastidic DOXP/MEP isoprenoid biosynthesis pathway detected by my group (see Lichtenthaler et al. 1997, Lichtenthaler 1999). The major contributions of this symposium were later published in the book 'The Chloroplast, Basics and Applications' with Tino Rebeiz as editor and me and several other colleagues as co-editors (Rebeiz et al. 2010). This book was published by Springer, Dordrecht, as volume 31 of Advances in Photosynthesis and Respiration, with Govindjee as 'Series Editor'. This sheds light to another major activity of Govindjee, i.e., being a passionate and sophisticated editor, always engaged to make new scientific results public to the colleagues of our large worldwide science community. In addition, I need to mention here that Govindjee gave at that symposium an excellent presentation on the now fully established two photosynthetic light and associated electron transport reactions leading to ATP and NADPH formation. Which enormous progress had been made by a multiple action of many well-known photosynthesis researchers, including Govindjee's and my contributions, in these 42 years after his first talk on this topic in 1963 at the ASPP meeting in Amherst!

During a lunch break at that symposium, Govindjee showed me the two memorial plaques on the university campus, one for Robert Emerson and the other for Eugene Rabinowitch. These plaques had been placed there just the day before. Of course, the initiative to commemorate these two great photosynthesis researchers, who both had worked at the University of Illinois and were his mentors, came from Govindjee. In addition, he invited me to his house where we had a wonderful tea hour together with his wife Rajni. He also showed me the house of Eugene Rabinowitch in Urbana, where Govindjee, already as graduate student, had often been invited.

\section{Activities with the Rebeiz Foundation}

During this 2005 symposium, Constantin Rebeiz, whom I knew very well from several photosynthesis meetings, told me that he had founded the Rebeiz Foundation for Basic Research, which in the future would give awards to selected top scientists for outstanding achievements in photosynthesis research. For this purpose, he had created a Board of Directors of the Rebeiz Foundation, which consisted of nine colleagues including Govindjee. The others were Christoph Benning, Hans Bohnert, Donald Bryant, Henry Daniell, William Lucas, Archie Portis, Harald Paulsen, Baishnab Tripathy and since 2010 also Tom Sharkey (see Rebeiz 2013, chapter 2.11, pages 58 and 59). Tino's wife, Carole Rebeiz, acted as Secretary General 
of the Foundation. This decision Board had to approve and select possible awardees. Tino also mentioned that he was planning to award the first Lifetime Achievement Award (LTA-Award) of the Rebeiz Foundation to Govindjee, and I encouraged him to do so. And in fact, Govindjee was the first recipient of this prestigious LTA-Award in 2006 which was presented to him in a dinner ceremony in 2007 at the Foundation. On this occasion, also several testimonials of colleagues on his scientific merits were read to the audience consisting of colleagues, Board members and guests of the Rebeiz Foundation.

During this 2005 symposium, Tino Rebeiz also mentioned that he would propose to the decision Board his former professor Paul Castelfranco, Davis, as next candidate for this Award planned for 2007. When being asked on further possible awardees, I told Tino that my friend Andy Benson (1917-2015), the co-detector of the Melvin-Calvin cycle of photosynthetic $\mathrm{CO}_{2}$ assimilation, would, in my opinion, be the most appropriate person. Andy was still alive then. I also mentioned that, together with two colleagues, I was preparing a special issue of Photosynthesis Research with papers dedicated to him for his $90^{\text {th }}$ anniversary in 2007 (Lichtenthaler et al. 2008). In 2008, Andy Benson indeed was elected as $3^{\text {rd }}$ recipient of the LTA-Award of the Rebeiz Foundation for Basic Research and I had written a short laudatio for him. Since at the Award ceremony in 2009 Andy Benson, then 92 years old, could no longer travel to Champaign, it was Govindjee - wearing a bow tie of Andy - who accepted this LTA-Award on behalf of Andy Benson. Later, further recipients of the LTA-Award of the Rebeiz Foundation were e.g., Robert Blankenship, St. Louis; Bob Buchanan, Berkeley; Roland Douce (1939-2018), Grenoble; and Diter von Wettstein (1929-2017), Pullman, and in total 12 recipients (see Table 1). In 2015, the decision Board of the Rebeiz Foundation selected me to receive the LTA-

Table 1. List of the twelve recipients of the Lifetime Achievement Award (LTA-Award) of the Rebeiz Foundation of Basic Research, Champaign, Illinois. The Awards were given in the years indicated, yet the corresponding award ceremony with handing over of the award plaques always proceeded in the following year.

\begin{tabular}{llll}
\hline Year & Number $^{\text {Name }}$ & Town \\
\hline 2006 & $1^{\text {st }}$ & Govindjee & Urbana \\
2007 & $2^{\text {nd }}$ & Paul Castelfranco & Davis \\
2008 & $3^{\text {rd }}$ & Andy A. Benson & La Jolla \\
2009 & $4^{\text {th }}$ & Diter von Wettstein & Pullman \\
2010 & $5^{\text {th }}$ & William L. Ogren & Urbana \\
2011 & $6^{\text {th }}$ & Bob Buchanan & Berkeley \\
2012 & $7^{\text {th }}$ & Wolfgang Junge & Osnabrück \\
& $8^{\text {th }}$ & André T. Jagendorf & Cornell \\
2013 & $9^{\text {th }}$ & Robert B. Blankenship & St. Louis \\
& $10^{\text {th }}$ & Roland Douce & Grenoble \\
2014 & $11^{\text {th }}$ & Hartmut K. Lichtenthaler & Karlsruhe \\
& $12^{\text {th }}$ & Pierre Joliot & Paris \\
\hline
\end{tabular}

Award for photosynthesis. Together with me also Pierre Joliot, Paris, was honored. I was the $11^{\text {th }}$ and Pierre Joliot the $12^{\text {th }}$ recipient of the LTA-Award, and we both were the last ones to receive this honor.

Govindjee and I met in Champaign the day before the ceremony as shown in Fig. 4. During the ceremony, four testimonials were presented for both recipients. And it was Govindjee who presented my laudatory speech. The other honoring speech was given by Tom Sharkey and both together wrote an article on this event for the journal Photosynthesis Research (Sharkey and Govindjee 2016). Fig. 5 shows Pierre Joliot and me together with Constantin Rebeiz at the Award ceremony at the Rebeiz Foundation. On the plaque of Pierre Joliot was indicated "for his discoveries in oxygen evolution and electron transport" and on my plaque "for his discoveries in chloroplast structure and isoprenoid biochemistry".

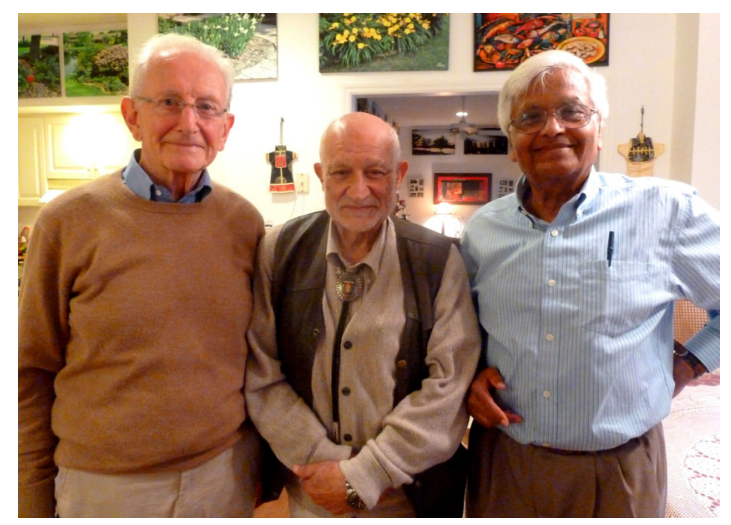

Fig. 4. Hartmut Lichtenthaler (left), Constantin Rebeiz (middle) and Govindjee (right) on September 12, 2015 in Champaign, Illinois, the day before Hartmut received the Lifetime Achievement Award of the Rebeiz Foundation, an award Govindjee had already received as the first one in 2007. (Photo from H.K. Lichtenthaler)

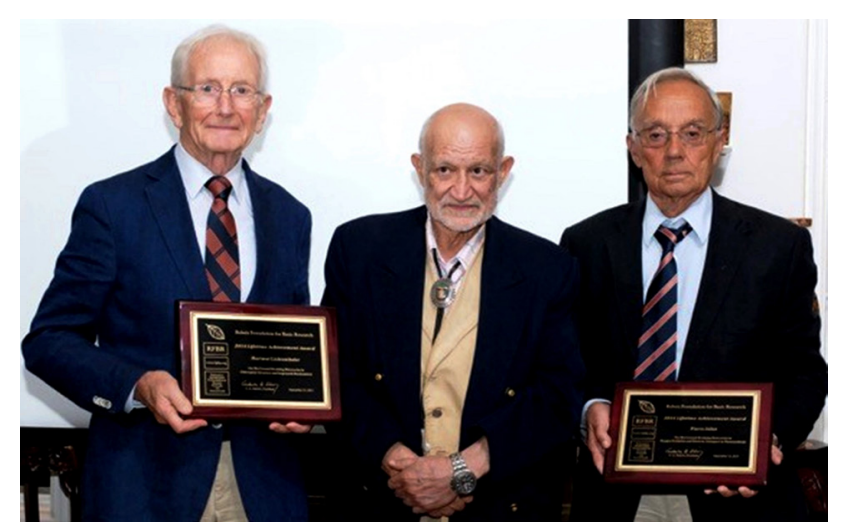

Fig. 5. Photo on September 13, 2015 at the Rebeiz Foundation, Champaign after the LTA-Awards 2014 for merits in photosynthesis had been handed over by Constantin Rebeiz (middle) to Hartmut Lichtenthaler (left) and Pierre Joliot (right). (Photo from Laurent Gasquet) 


\section{Further activities}

In 2015, Andy Benson, the outstanding biochemist and pioneer of photosynthesis and plant lipid research, passed away in La Jolla. It is particular noteworthy that his 'Obituary and Tribute' was written by four scientists active in photosynthesis research, all of them friends of Andy Benson, who - like Andy Benson - had also received the LTA-Award for Photosynthesis of the Rebeiz Foundation. These were Bob Buchanan, Roland Douce, Govindjee, and me (Lichtenthaler et al. 2015). One of our most recent joint activities was to write the tribute 'Remembering Melvin Calvin (1911-1997)', which came out in Photosynthesis Research (Govindjee et al. 2020b). Another one was to translate the doctoral thesis of Robert Emmerson, then written in German language since he had received his Ph.D. with Otto Warburg in Berlin, into English language. Of course, the idea and encouragement came from Govindjee, and the translation was performed by Lars Olof Björn and me (Lichtenthaler and Björn 2020). And this paper was preceded by a Letter to the Editor of Govindjee on Emerson (Govindjee 2020).

In summary, it was a pleasure and privilege having met Govindjee so early in our scientific careers and then again and again over the years. Our cooperation and friendship is now lasting for many decades and will continue in the future. This year he celebrates his $88^{\text {th }}$ birthday. Along with many colleagues of our worldwide photosynthesis community, I wish him a stable health, many happy returns and many further activities as outstanding science communicator and passionate author of historical perspectives in photosynthesis.

\section{References}

Blankenship R.E.: Molecular Mechanisms of Photosynthesis. $2^{\text {nd }}$ Edition. Pp. 312. John Wiley and Sons, Chichester 2014.

Butler W.L.: Effects of red and far-red light in the fluorescence yield of chlorophyll in vivo. - Biochim. Biophys. Acta 64: 309-317, 1962.

Duysens L.N.M., Amesz J., Kamp B.M.: Two photochemical systems in photosynthesis. - Nature 190: 510-511, 1961.

Duysens L.N.M., Sweers H.E.: Mechanisms of two photochemical reactions in algae as studied by means of chlorophyll fluorescence. - In: Japanese Society of Plant Physiologists (ed.): Studies on Microalgae and Photosynthetic Bacteria. Pp. 353-372. University Press, Tokyo 1963.

Eaton-Rye J.J.: Govindjee: a lifetime in photosynthesis. Photosynth. Res. 139: 9-14, 2019.

Emerson R., Chalmers R., Cederstrand C.: Some factors influencing the long-wave limit of photosynthesis. - P. Natl. Acad. Sci. USA 43: 133-143, 1957.

Franck J., French C.S., Puck T.T.: The fluorescence of chlorophyll and photosynthesis. - J. Phys. Chem. 45: 1268-1300, 1941.

Franck U.F., Hoffmann N., Arenz H., Schreiber U.: Chlorophyllfluoreszenz als Indikator der photochemischen Primärprozesse der Photosynthese. [Chlorophyll fluorescence as indicator of the photochemical primary processes of photosynthesis.] Ber. Bunsenges. Phys. Chem. 73: 871-879, 1969. [In German]

Govindjee G.: Robert Emerson, a major discoverer of photosynthesis, had pioneered research in respiration in the 1920s, under Otto Warburg. - J. Plant Sci. Res. 36: 1-4, 2020.

Govindjee G., Briskin D.P., Benning C. et al.: From $\delta$-aminolevulinic acid to chlorophyll and every step in between: In memory of Constantin (Tino) A. Rebeiz, 19362019. - Photosynth. Res. 143, 2020a. (In press) https://doi. org/10.1007/s11120-020-00750-x.

Govindjee G., Nonomura A., Lichtenthaler H.K.: Remembering Melvin Calvin (1911-1997), a highly versatile scientist of the 20th century. - Photosynth. Res. 143: 1-11, 2020b.

Govindjee: Emerson enhancement effect and two light reactions in photosynthesis: Dedicated to the memory of late professor Robert Emerson. - In: Kok B., Jagendorf A.T. (ed.): Photosynthetic Mechanisms of Green Plants. Publication 1145. Pp. 318-334. Natl. Acad. Sci. Natl. Res. Council, Washington 1963.

Govindjee: Sixty-three years since Kautsky: chlorophyll $a$ fluorescence. - Aust. J. Plant Physiol. 22: 131-160, 1995.

Govindjee, Amesz J., Fork D.C. (ed.): Light Emission by Plants and Bacteria. Pp. 660. Academic Press, Orlando 1986.

Govindjee, Ichimura S., Cederstrand C., Rabinowitch E.: Effect of combining far-red light with shorter wave light on the excitation of fluorescence in Chlorella. - Arch. Biochem. Biophys. 89: 322-323, 1960.

Govindjee, Marcelle D.: René Marcelle (December 30, 1931December 18, 2011), the first editor-in-chief of Photosynthesis Research. - Photosynth. Res. 129: 13-15, 2016.

Govindjee, Pulles M.P.J.: Louis Nico Marie Duysens (March 15, 1921-September 8, 2015): A leading biophysicist of the twentieth century. - Photosynth. Res. 128: 223-234, 2016.

Govindjee, Šesták Z., Peters W.R.: The early history of "Photosynthetica", "Photosynthesis Research" and their publishers. - Photosynthetica 40: 1-11, 2002.

Holub O., Seufferheld M.J., Gohlke C. et al.: Fluorescence lifetime imaging (FLI) - a new technique in photosynthesis research. - Photosynthetica 38: 581-599, 2000.

Holub O., Seufferheld M.J., Gohlke C. et al.: Fluorescence lifetime imaging microscopy of Chlamydomonas reinhardtii: non-photochemical quenching mutants and the effect of photosynthetic inhibitors on the slow chlorophyll fluorescence transient. - J. Microsc. 226: 90-120, 2007.

Interschick-Niebler E., Lichtenthaler H.K.: Partition of phylloquinone $\mathrm{K}_{1}$ between digitonin particles and chlorophyllproteins of chloroplast membranes from Nicotina tabacum. Z. Naturforsch. 36c: 276-283, 1981.

Joyard J., Lichtenthaler H.K.: Roland Douce, 1939-2018. Photosynth. Res. 141: 131-142, 2019.

Kautsky H., Appel W., Amann H.: Chlorophyll und Kohlensäureassimilation. XIII. Die Fluoreszenzkurve und die Photochemie der Pflanze. [Chlorophyll and carbon dioxide assimilation. XIII. The fluorescence curve and the photochemistry of the plant.] - Biochem. Z. 332: 277-292, 1960. [In German]

Kautsky H., Franck U.: Die Chlorophyllfluoreszenz von Ulva lactuca und ihre Abhängigkeit von Narcotica, Sauerstoff und Kohlendioxid. [The chlorophyll fluorescence of Ulva lactuca and its dependence on narcotics, oxygene and carbon dioxide.] - Biochem. Z. 315: 176-206, 1943. [In German]

Kautsky H., Hirsch A.: Neue Versuche zur Kohlensäureassimilation. I. Mitteilung: Das Fluoreszenzverhalten grüner Pflanzen. [New assays on carbon dioxide assimilation. I. Communication. The fluorescence behaviour of green plants.] Naturwissenschaften 19: 964, 1931. [In German]

Lichtenthaler H.K.: Localization and functional concentrations of lipoquinones in chloroplasts. - In: Metzner H. (ed.): Progress in Photosynthesis Research. Vol. 1. Pp. 304-314. H. Laupp, Tübingen 1969.

Lichtenthaler H.K. (ed.): Applications of Chlorophyll Fluorescence in Photosynthesis Research, Stress Physiology, Hydrobiology and Remote Sensing. Pp. 366. Kluwer 
Academic Publishers, Dordrecht 1988.

Lichtenthaler H.K.: The Kautsky effect: 60 years of chlorophyll fluorescence induction kinetics. - Photosynthetica 27: 45-55, 1992.

Lichtenthaler H.K.: The 1-deoxy-D-xylulose-5-phosphate pathway of isoprenoid biosynthesis in plants. - Annu. Rev. Plant Phys. 50: 47-65, 1999.

Lichtenthaler H.K.: A history of the Federation of European Societies of Plant Physiology FESPP since its formation in 1978 - including notes on events preceding the foundation and following re-naming as the Federation of European Societies of Plant Biology (FESPB) in 2002. - J. Plant Physiol. 161: 635-639, 2004a.

Lichtenthaler H.K.: Thirty years of international symposia on plant lipids. - In: Biacs P., Gerely P. (ed.): Proceedings of the $16^{\text {th }}$ Plant Lipid Symposium. Pp. I-XXXI. Mete Publisher, Budapest 2004b. Available at: http://www.isp12012.org/ documents/ISPL_History.pdf

Lichtenthaler H.K.: Zdeněk Šesták and Photosynthetica, a tribute. - Photosynthetica 56: 1-6, 2018.

Lichtenthaler H.K., Ač A., Marek M.V. et al.: Differences in pigment composition, photosynthetic rates and chlorophyll fluorescence images of sun and shade leaves of four tree species. - Plant Physiol. Bioch. 45: 577-588, 2007.

Lichtenthaler H.K., Babani F., Langsdorf G., Buschmann C.: Measurement of differences in red chlorophyll fluorescence and photosynthetic activity between sun and shade leaves by fluorescence imaging. - Photosynthetica 38: 521-529, 2000.

Lichtenthaler H.K., Babani F.: Light adaption and senescence of the photosynthetic apparatus: changes in pigment composition, chlorophyll fluorescence parameters and photosynthetic activity during light adaptation and senescence of leaves. In: Papageorgiou G.C., Govindjee (ed.): Chlorophyll Fluorescence: A Signature of Photosynthesis. Pp. 713-736. Springer, Dordrecht 2004.

Lichtenthaler H.K., Björn L.O.: English translation of the 1927 doctoral thesis (in German) of Robert Emerson, a pioneer in photosynthesis. - J. Plant Sci. Res. 36: 5-14, 2020.

Lichtenthaler H.K., Buchanan B.B., Douce R., Govindjee: Andrew A. Benson, 1917-2015. - Photosynth. Res. 124: 131$135,2015$.

Lichtenthaler H.K., Buchanan B.B., Douce R.: Honoring Andrew Benson in Paris: A tribute on his 90th birthday. - Photosynth. Res. 96: 181-183, 2008.

Lichtenthaler H.K., Buschmann C., Knapp M.: How to correctly determine the different chlorophyll fluorescence parameters and the chlorophyll fluorescence decrease ratio $\mathrm{R}_{\mathrm{Fd}}$ of leaves with the PAM fluorometer. - Photosynthetica 43: 379-393, 2005a.

Lichtenthaler H.K., Calvin M.: Quinone and pigment composition of chloroplasts and quantasome aggregates from Spinacia oleracea. - Biochim. Biophys. Acta 79: 30-40, 1964.

Lichtenthaler H.K., Langsdorf G., Lenk S., Buschmann C.: Chlorophyll fluorescence imaging of photosynthetic activity with the flash-lamp fluorescence imaging system. -
Photosynthetica 43: 355-369, 2005 b.

Lichtenthaler H.K., Miehé J.A.: Fluorescence imaging as a diagnostic tool for plant stress. - Trends Plant Sci. 2: 316320, 1997.

Lichtenthaler H.K., Park R.B.: Chemical composition of chloroplast lamellae from spinach. - Nature 198: 1070-1072, 1963.

Lichtenthaler H.K., Rinderle U.: The role of chlorophyll fluorescence in the detection of stress conditions in plants. CRC Crit. Rev. Anal. Chem. 19: S29-S85, 1988.

Lichtenthaler H.K., Schwender J., Disch A., Rohmer M.: Biosynthesis of isoprenoids in higher plant chloroplasts proceeds via a mevalonate independent pathway. - FEBS Lett. 400: 271-274, 1997.

Matsubara S., Chen Y.C., Caliandro R. et al.: Photosystem II fluorescence lifetime imaging in avocado leaves: Contributions of the lutein-epoxide and violaxanthin cycles to fluorescence quenching. - J. Photoch. Photobio. B 104: 271284, 2011.

Munday J.C., Govindjee: Fluorescence transients in Chlorella: Effects of supplementary light, anaerobiosis, and methylviologen. - In: Metzner H. (ed.): Progress in Photosynthesis Research. Vol. 2. Pp. 913-922. H. Laupp, Tübingen 1969.

Papageorgiou G.C., Govindjee (ed.): Chlorophyll a Fluorescence: A Signature of Photosynthesis. Advances in Photosynthesis and Respiration. Pp. 818. Springer, Dordrecht 2004.

Papageorgiou G.C., Govindjee: The "second wave" of fluorescence induction in Chlorella pyrenoidosa. - In: Metzner H. (ed.): Progress in Photosynthesis Research. Vol. 2. Pp. 905-912, H. Laupp, Tübingen 1969.

Pfister K., Buschmann C., Lichtenthaler H.K.: Inhibition of the photosynthetic electron transport by bentazone. In: Proceedings of the $3^{\text {rd }}$ International Congress on Photosynthesis. Vol. 1. Pp. 675-681. Elsevier Scientific Publishing Company, Amsterdam 1974.

Rebeiz C.A.: Chlorophyll Biosynthesis and Technological Applications. Pp. 469. Springer, Dordrecht 2013.

Rebeiz C.A., Benning C., Bohnert H.J. et al. (ed.): The Chloroplast: Basics and Applications. In: Govindjee, Sharkey T.D. (ed.): Advances in Photosynthesis and Respiration. Vol. 31. Pp. 426. Springer, Dordrecht 2010.

Seybold A., Egle K.: Lichtfeld und Blattfarbstoffe I. [Light field and leaf pigments I.] - Planta 26: 491-496, 1937. [In German]

Sharkey T.D., Govindjee: Hartmut Lichtenthaler: an authority on chloroplast structure and isoprenoid biochemistry. Photosynth. Res. 128: 117-123, 2016.

Stirbet A., Govindjee: On the relation between the Kautsky effect (chlorophyll $a$ fluorescence induction) and photosystem II: Basics and applications of the OJIP fluorescence transient. J. Photoch. Photobio. B 104: 236-257, 2011.

Vredenberg W.J., Govindjee G.: Christiaan Sybesma (August 31, 1928-January 31, 2018), an extraordinary biophysicist of our time. - Photosynth. Res. 144: 297-300, 2020.

Wassink E.C., Katz E.: The initial changes of chlorophyll fluorescence in Chlorella. - Enzymologia 6: 145-172, 1939.

(C) The authors. This is an open access article distributed under the terms of the Creative Commons BY-NC-ND Licence. 